\title{
THE CORPORATE GOVERNANCE DEBATE ON PROFESSIONAL ETHICS IN THE ACCOUNTING PROFESSION
}

\author{
Bonaci, C. G., Strouhal, J., Müllerová, L., Roubíčková, J.
}

This paper focuses on the particular case of professional ethics in the context of the accounting profession. After briefly discussing recent events that made us reconsider our understanding of corporate governance, accountancy and ethics, we attempt to delimit the state of the art by looking at ethics from the accounting profession's perspective. When aiming to clarify professional ethics, we closely analyze integrity based on the latest developments undertaken by European professional bodies. The findings are used in identifying ways to contribute to the endeavor of aligning the profession's performance with society's reasonable expectations.

JEL classification: M41, G30

Keywords: Business ethics; accounting profession; auditing; code of ethics.

\section{Introduction}

The word "ethics" is derived from the Greek word "ethos" and is linked especially to Aristotle who defined ethics as the science of a good life. We can say this word has several more meanings in the philosophical dictionary. "At the origin of human history the moral principles, ethos or morality were related particularly to custom, i.e. to practical behavior standards which at first corresponded to the total needs of solidarity, to a greater extent than internal subjective needs of an individual. This internal need of subjective moral consciousness is created only by becoming accustomed, by social practice and by education on a step-by-step basis. "Ethics, in modern society, is related not only to the system of moral standards, but also to personal behavior and responsibility for the consequences of taken decisions as well.

Professional ethics in various professions is nothing more than a subset of general ethics. Mautz and Sharef (quoted by Králíček and Müllerová, 1998) state that "ethical manner in auditing is nothing more than a specific application of general understanding of ethical manner developed by the philosopher".

In the context of a worldwide recession caused by excessive credit expansion (Walker, 2010), central elements of corporate governance, such as executive remuneration, internal control, risk management, the board of directors, independent non-executive directors, and shareholders' roles are nowadays being reconsidered and closely analyzed. Financial institutions, using structured financial instruments, assume their buying and reconstruction within an even more complicated structure if possible and afterwards their selling at a higher price to other financial institutions. The new buyers will and did of course follow the same recipe. It seems that this category of derivative financial instruments enjoyed the appreciation of nowadays sophisticated banks which seemed to be anxious in actually risking their shareholders' money in order to invest in complex structured instruments some knew only a little about (Butler, 2009). That is why investigations searching to find exactly how things got the way they did and turned into such a serious financial crisis are now focusing their attention on those beings responsible for trading these instruments. Under poor corporate governance settings, one of the risks that became obvious from the above presented discussion is that accountants might be pressured by directors in order to present a reflection that is likeable for the shareholders, but sometimes miles away from the economic 
truth. Using structured financial instruments creates a series of difficulties from the financial reporting point of view, such as fair value measurements through the use of mark to model valuation.

An important aspect that must be considered is avoiding the development of reward systems for directors and other employees that act as traders that allow the hiding of mistakes being made within their activity. When such systems exist there is also the possibility of consequences reaching up to the level of accounting practices and putting pressure on accountants as well. This practice actually represents a reality that comes up in history starting with the first financial scandals that shook the accounting environment at the beginning of the $21^{\text {st }}$ century (e.g. Enron, World.com, etc.). Directors being able to obtain huge rewards even when considering cases that ended up with monumental bankruptcies and failures tempt them into undertaking exaggerated risks. The natural consequence will afterwards be for them to try and hide these risks and the potential losses therefore being generated for as long as possible. We are dealing here with moral hazard issues, an inappropriate rewards system enhancing directors' behavior in maximizing their own bonuses while sometimes even destroying value from shareholders' point of view (Beaver, 1998). Accounting professionals and their relation to stakeholders represent an essential component when considering corporate governance mechanisms. Furthermore, agency theory describes the complexity of the relation between shareholders and managers. While working with managers, accountants should aim for the faithful representation with informational content for stakeholders. Considering the complexity of their position, we find accounting ethics and professionalism to play an important role when constructing sound corporate governance structures.

The respect to certain ethical standards among the auditors has become as important as the profession itself. This necessity is more apparent in the context that Czech auditors are more often linked with the international environment. It's not only because many companies with international ownership interest in our market have an obligation to have their financial statements audited and their owners are used to gaining audit services of certain quality. The next important fact is that the Chamber of Auditors of Czech Republic has been a member of the International Federation of Accountants (IFAC) since 1994. Membership in this international body associating national professional organizations of auditors and professional accountants from the whole world is not only characterized by the high expertise of its members but also by respecting fundamental ethical rules such as independence, objectivity, expert assumptions and appropriate care, confidential character of information, and professional behavior in compliance with the standards on auditing as well. These rules are specified in the International Ethical Code of Auditors and Accountants approved by the Chamber of Auditors of the Czech Republic too.

The importance of regulation of the accounting profession is continuously increasing, particularly in connection with the assumed integration of the Czech Republic into international structures. The liberalization of the accounting profession which is expected in the European Union places huge demands on professional expertise with the request of strict control of this expertise, quality of provided services and following the ethical standards at the same time. Free mobility of workers among the EU members demands to ensure the comparable level of accounting profession in each member state and at the same time to secure its high professional levels.

The idea is further developed through the remainder of the paper being organized as follows: we first try to delimit the state of the art by looking at ethics from the accounting profession's perspective. After discussing some theoretical aspects we follow accountants' development starting with their education and training as students and continue with them entering the profession, which should further impose continuous training. Codes of ethics and their role for the profession are also discussed in this part of the paper. We then consider the issue of some well-known financial scandals that represent the argument for the current debate on business ethics. Aspects related to the employed research methodology are presented. Our analysis further focuses on integrity in professional ethics by considering FEE's recent initiatives and presenting some further developments. The main findings of our paper are synthesized within the conclusion.

\section{A Brief Insight to the Trade Literature}

Trying to place ethics in the economic context, one can use Friedman's (1988) argument that profit-oriented businesses must meet their social responsibilities by accepting the restraints being imposed through society's basic rules, both those comprised within the law and those incorporated within ethical content. Adam Smith's vision regarding the invisible hand emphasizing entrepreneurs' self-interest transforms the business market into a market that is incompatible with moral interferences. Bernard Mandeville's opinion places shareholders self assessing their behavior as a sine qua non 
condition for economic prosperity and the driving force for society's civilization process, all these being critically reflected over time.

A continuous fight for profit that is led by avarice and greed breaks the notion of justice and is therefore incompatible with the universal and humanistic concept of justice. Consequently, maintaining ethics in the business world can be done when the business environment imposes efficient self-regulation measures that exceed the high number of laws and regulations being adopted by governmental bodies and requirements being imposed by regulatory bodies. As long as businesses have an individual character, we must work towards a personal sense of morality that must be developed by considering deontological principles in codes of ethics. Ethical responsibility in the business world is not holistic, but what we can do is consider any phenomenon that within a certain context influences ethical behavior (Micewski and Troy, 2006).

The role of accounting ethics is to ensure a system of information that would encourage and support rational behavior. Accountants are not held responsible for the structure within which they produce and communicate information, nor for the purpose of that information. One of the main purposes that should be considered throughout accountants' continuous professional evolution is the development of moral judgment. The necessity of maintaining public trust in the integrity of the accounting profession has led to an increase in the number of studies analyzing moral judgment abilities. Most of the studies look at accountants working within large companies (especially the Big 4), while only a few (such as Eynon et al., 1997) consider little entities or accountants working on their own. The main thing that differentiates the above mentioned categories of accountants is their working environment, large companies bringing the benefit of cooperation with colleagues, in-house training and organizational support.

Ethics looks at human behavior, moral principles and the attempt to distinguish good from bad. When trying to identify common issues being dealt with within the business environment, professional bodies' codes of ethics are the right place to look. These codes represent what we can consider to be the reflection of business ethics. Codes of ethics should mainly address the particularities of high risk activities and are built on the collective conscience of a profession as proof for the group's acknowledgment of the moral dimension. In the case of the accounting profession, we should mention the International Federation of Accountants' (IFAC) code of ethics establishing the standards for accounting profes- sionals' behavior and displaying the fundamental principles they should respect in order to fulfill their common objectives. IFAC's code of ethics generally adopts a principles-based approach. The five fundamental principles in the IFAC code are: integrity; objectivity; professional competence and due care; confidentiality; and professional behavior.

Accountants, employees working in financial control and top managers accept responsibilities with regard to financial reporting and providing information that investors should be able to use in the decision-making process. This information is also being used in assessing management's performance. Auditors accept the responsibility to examine financial situations being filed by the companies' employee and asses their conformity with the financial reporting standards. Accounting academics accept responsibilities related to professional development that will stand at the basis of their professional activity. Regulators and standards setting bodies also take responsibilities with regard to the financial reporting standards that will help faithfully represent economic realities. It is large financial scandals that make us reconsider the attributions of the above mentioned groups and to what extent they are being carried out.

Significant financial consequences usually draw the alarm regarding ethical failures. When management decides on the remuneration of auditors or of the board members, we can speak about complete independence. We will therefore have no independent control over management's reporting of its own performance except for the role being played by the auditor and the fear of sanctions in case failure is detected. The recent financial crisis represents a good example of managers and traders undertaking significant risks that further impacted upon shareholders. Ignoring corporate governance principles led to a series of worldwide known financial scandals such as Barings Bank, IBM-Hitachi, Lehman Brothers, Drexel Burnham Lambert, Enron, WorldCom and Parmalat. Ethical behavior can be questioned in many of the above cases for a number of involved parties. We will therefore further focus on developing a conceptual framework that would enhance accounting professionals' ethics and help them contribute to accountancy in the context of sound corporate governance structures.

\section{Research Design}

As we were previously discussing, the accountant's role is to give a faithful representation of economic realities. Integrating ethics into an accountant's role, we consider the following interactions: a high level of ethical behavior would make it easier for the accountant to give a fair 
representation of the economic reality, while compromises from an ethics point of view might move their actions towards creative accounting and even fraud. The following figure reflects our reasoning:

Figure 1: Accounting professionals' ethics and the result of their work

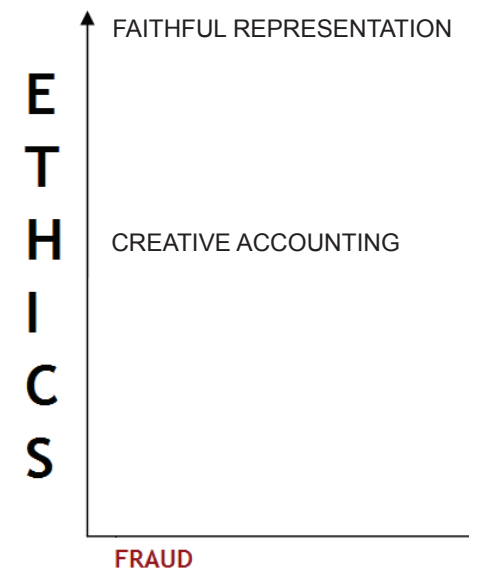

Source: Authors' analysis

As can be seen from the above presented figure, when dealing with fraud we cannot speak about ethics. Creative accounting takes a big part of the representation due to its complex interpretations. Used in good faith, it should help the accountant reach a faithful representation taking us to the superior area of the figure. On the other hand, it can also lead to manipulation, which takes us closer to the fraud area. Faithful representation is assumedly linked with the highest degree of ethics. Despite all these, we consider it a good way to argue for the importance of ethics in relation to the accounting profession. Closely analyzing accountants' ethical behavior first helps from the perspective of their current activities in which they might face ethical dilemmas and the manner in which they will be solved further impacts upon the results of their work and therefore stakeholders.

\section{Results}

The manner in which ethics is incorporated into accounting professionals' activity naturally impacts upon the comparability of the accounting information being provided. This also brings the globalization process into the picture, or more precisely the accounting harmonization process. Since ethics represents a complex and philosophic enough concept, we will focus our analysis from a regional perspective by looking at the latest developments in the area belonging to the Federation of European Accountants (FEE - Fédération des Experts
Comptables Européens). We previously mentioned the five fundamental principles in the IFAC code of ethics, integrity being one of them. It was in September 2009 that FEE released a discussion paper on integrity in professional ethics, emphasizing the importance of this particular principle. Furthermore, a FEE press release from April 2011 stated that personal and professional integrity is the first and foremost ethical principle for behavior in business (FEE, 2011b).

We consider the discussion paper issued in September 2009 to represent a significant step in its demarche to clarify professional ethics. It is the FEE Annual Review that features the fundamental values and principles of professional accountants as being derived from IFAC's Code of Ethics. Therefore integrity is defined as being straightforward and honest in professional and business relationships, fair dealing and truthfulness, and not being associated with information that contains materially false or misleading statements or information furnished recklessly. The discussion paper underlines that in taking into account the public interest, the professional accountant's responsibility is not exclusively to satisfy the needs of individual clients or employers. This is critical because of the need to align the performance of the profession with society's reasonable expectations (FEE, 2009). The philosophy of the analyzed context is underlined by using Francis Bacon's argument that: It's not what we eat but what we digest that makes us strong; not what we gain but what we save that makes us rich; not what we read but what we remember that makes us learned; and not what we profess but what we practice that gives us integrity.

The discussion paper comprises an introduction and a background part and afterwards considers the importance and meaning of integrity, behaving with integrity, integrity in organizations, the role of individual accounts and the role of FEE member bodies. A number of 30 responses were received for the discussion paper. Respondents were FEE member bodies, audit firms, other professional accounting bodies, other professional bodies, regulators and individuals. The consultation brought interesting observations regarding the meaning of integrity and how it is instilled in the respondents' own organizations (FEE, 2011a). Respondents' arguments documented FEE's consideration of integrity as the core fundamental principle from which the others are derived. Its interaction with the other principles and their importance was still underlined by some respondents. Threats to integrity were interpreted to vary depending on the economic period (downturn or boom). The idea was further supported by FEE president, Philip John- 
son stating that it will be key to look at how codes of ethics and disciplinary arrangements can respond better to unethical behavior in the different economic cycles (FEE, 2011b).

In relation to the interaction of personal and professional integrity, respondents agreed that personal character was relevant to professional integrity, but the effect of this on accountancy bodies' disciplinary arrangements raised mixed opinions. When asked whether it would be helpful for the accountancy professional bodies' codes of ethics to include more discussion on integrity, the small majority favoring this pleaded for coordination on the international level (such as IFAC). Respondents also agreed that the individual accountant has a responsibility, though this will vary according to the circumstances, but once again disagreed as to where additional useful guidance in this regard could come from (FEE, 2011a). Another significant aspect revealed through the consultation process is that the integrity of organizations is a relevant matter and that further analysis and guidance on how to promote such integrity and determine to which extent it exists in an organization may be useful.

As Michael Niehues, chairman of FEE's Ethics Working Party underlined, further debate at different levels on the characteristics of integrity, possible guidance and the way accountants can promote (organizational) integrity is strongly favored (FEE, 2011b). Discussing and trying to clarify integrity represents only one part in the complexity of professional ethics. FEE (2011a) already suggested further actions such as a round table discussion, academic research, a booklet for educational purposes highlighting the key message of integrity (both personal and corporate), seeking to interest other organizations in the work, like the International Ethics Standards Board for Accountants (IESBA) and national ethics standard setters but also academic researchers and other organizations which are connected to the auditing world. We find these perspectives to offer insights and potential ways for many of us to contribute to the interesting debate on professional ethics.

\section{Conclusions and Implications}

During recent decades, public interest for business ethics has significantly increased due to an apparently continuous flow of business fraud and fraudulent management. It therefore doesn't surprise us that public trust in businesses and accountants is decreasing. This represents our argument for finding ways to incorporate ethics both within the educational environment and accounting prac- tice. We consider accounting education should be viewed as a potential remedy for the professional ethics crisis. If we want to have ethical professionals, we should start including ethics in their education early so that there will be no differences between their initial training and its continuation. When looking at the academic environment, students already have significant background that should have built the foundations of their ethics as persons. Therefore, teaching ethics to accounting students should no longer try to convince them that they should act in an ethical manner, but raise their awareness with regard to ethical issues in accounting practices. This should aim at enhancing their analytical abilities and develop a sense of moral obligation. In this regard, research literature discusses three main methods of teaching ethics in accounting such as: as a separate class, integrated within other classes, or both two approaches. Accounting education has been criticized for its inability to adequately develop competences that are necessary for students when being faced with ambiguous and unstructured problems. Educators were, in this regard, recommended to use alternative teaching methods that would develop students' critical thinking together with a series of aptitudes and competences. Studies such as Alam (1998) have documented the development of moral values to be among the educational objectives as seen by employers for some time now. In this regard, educators should consider simulating an attractive business environment within the classroom, organizing workshops aimed to develop abilities and competences, inviting speakers from the business environment, etc. Some consider that practitioners should also be consulted when establishing the curriculum. Finding ways for students to be involved in practice and have internships within different companies as well as educators using real examples and case studies is also strongly recommended. Summing up, educators should make sure students acknowledge the financial and social implications of their business decisions.

Our findings are also consistent with Smith's (2003) argument that those who govern the accounting profession as well as academics have the responsibility to imprint ethical behavior and personal integrity within students' and practitioners' minds. This would be the only way to restore the accounting profession's credibility, which was significantly hindered by a series of ethical failures. Encouraging ethical behavior would not only discourage fraud, but would also help us contribute to the state of accountancy that would make us proud of our profession. 


\section{References}

Alam, K. F. (1998). Ethics and Accounting Education. Teaching Business Ethics, 2(3): 261-272.

Beaver, W. (1998). Financial Reporting: An Accounting Revolution. 3rd Edition. London: Prentice-Hall.

Bohatá, M. (1997). Etika a integrita $v \check{C} R$. Prague: European Business Ethics Network Seminar.

Butler, C. (2009). Accounting for Financial Instruments. New York: John Willey \& Sons.

Eynon, G., Thorley, N., Stevens, K. T. (1997). Factors that Influence the Moral Reasoning Abilities of Accountants: Implications for Universities and the Profession. Journal of Business Ethics, 16(12-13): 1297-1309.

Federation of European Accountants (2009). Integrity in Professional Ethics. A Discussion Paper.

Federation of European Accountants (2011a). Analysis of Responses to FEE Discussion Paper on Integrity in Professional Ethics. A Comment Paper.

Federation of European Accountants (2011b). Personal and Professional Integrity: At the Core for Accountants and Business in General.

Friedman, M. (1988). Money and the Sock Market. Journal of Political Economy, 96(2): 221-245.

Králíček, V., Müllerová, L. (1998). Auditing. Prague: Svaz účetních.

Micewski, E. R., Troy, T. (2006). Business Ethics - Deontologically Revisited. Journal of Business Ethics, 72(1): 17-25.

Smith, M. (2003). A Fresh Look at Accounting Ethics. Accounting Horizons, 17(1): 47-49.

Walker, M. (2010). Accounting for Varieties of Capitalism: The Case against a Single Set of Global Accounting Standards. The British Accounting Review, 42: 137-152.
Authors

Dr. Carmen Giorgiana Bonaci Associate Professor Babes-Bolyai University Cluj Napoca, Department of Accounting

T. Mihali 58-60, 400592 Cluj Napoca, Romania carmen.bonaci@econ.ubbcluj.ro

Dr. Jiří Strouhal

Associate Professor

University of Economics Prague,

Department of Business Economics

W. Churchill Square 4, 13067 Prague 3,

Czech Republic

strouhal@vse.cz

Prof. Dr. Libuše Müllerová

Professor

University of Economics Prague, Department of

Financial Accounting and Auditing

W. Churchill Square 4, 13067 Prague 3,

Czech Republic

muller@vse.cz

Dr. Jaroslava Roubíčková

Associate Professor

University of Economics Prague, Department of

Financial Accounting and Auditing

W. Churchill Square 4, 13067 Prague 3,

Czech Republic

roubicko@vse.cz

This paper is one of the research outputs of the project P403/11/0002 registered at Czech Science Foundation (GAČR). 